Vol. 4, No. 1, January 2016

Jurnal llmial

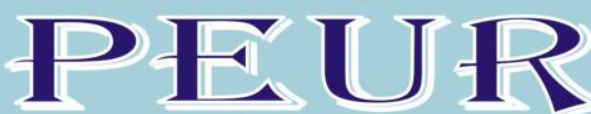

Media Kajian Ilmiah Sosial, Politik, Hukum, Agama dan Budaya
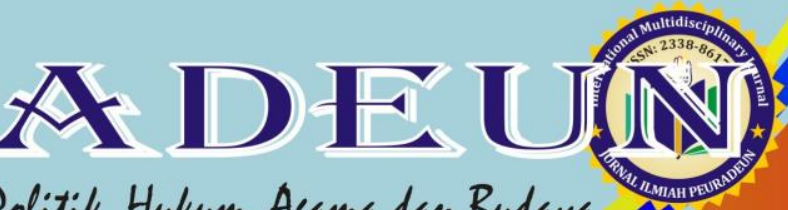


\title{
ALTERNATIVE CONTROL OF INSECT PESTS IN VEGETABLE PLANTS USING LOCAL WISDOM APPROACH
}

\section{Lukmanul Hakim and Abdul Muis}

Faculty of Agricultural Technology, Serambi Mekkah University, Banda Aceh, Indonesia E-mail : l.hakim92@ymail.com

Received: Jul 20, 2015

Article Url: https://journal.scadindependent.org/index.php/jipeuradeun/article/view/85

\begin{abstract}
This research aimed to determine the local wisdom of the community of Lembah Seulawah Sub-district, Aceh Besar, Indonesia of controlling insect pests in vegetable plants. In addition, the study intended to examine the impact of using paper as a mechanical trap for insect pests in vegetable plants. Both qualitative and quantitative methods were used in this research. The qualitative data were obtained through interviews with farmers, whereas the quantitative data were collected from an experiment. Thirty randomly-selected respondents were interviewed and then the qualitative and quantitative data processing was performed. The results showed that they still use plant-based materials as insecticides which constitute the local wisdom of controlling insect pests in vegetable plants. The plants used as insecticides were, among others, garlic (Allium satifum), castor bean seeds (Ricinus communis), lemongrass, neem seeds, and thorny amaranth as the trap plants.
\end{abstract}

Keywords: Alternative Control, Local Wisdom, Vegetable Plants 


\section{A. Introduction}

Insects are a dominant group of animals which constitutes $80 \%$ of all animals existing on earth (Borror DJ. CA Triplehorn, NF Johnson, 1996: 76). Therefore, it is very reasonable that insects are highly successful in their survival which involves interaction with plants and human beings. One advantage of insects over other animals is their great reproduction ability (Oka Ida Nyoman 1993:134). Insects live in an agricultural ecosystem continuously because it enables them to obtain sufficient food.

Untung Kasumbogo (1984: 28) stated that an ecosystem is a system formed by a dynamic interaction between abiotic and biotic components. An ecosystem is defined as a complex and interactive unit comprising all organisms living in a certain area and in the entire physical environment.

Based on the above-mentioned definition of the life system, we should focus the analysis on the mutual relationship among the organisms living in an ecosystem in order to be able to manage insect pests (Untung Kasumbogo, 1993: 79). Human beings have a bigger role than other living organisms, thus they tend to overuse their authority, primarily in their effort to maintain the balance of an ecosystem. An ecosystem's balance is highly determined by the interaction between one system and the others. Insects are a source of food of other animals but they also are dependent on plants for food. As a result, insects may turn into pests for plants when their populations soar. To control the insect population, wise control strategies are required in order to maintain a sustainable ecosystem (Oka Ida Nyoman, 1993:135).

The local wisdom approach to insect pest control is still relevant up to now because it can wisely address the changes taking place in an agricultural ecosystem. Local wisdom is the culture of a community that has long been carried out and handed down from one generation to another. However, this tradition almost disappears from the people's lives in this era of advanced technology leading to practical reasoning. Law Number 23 Year 1997 Article 1 Clause 2 on Environment stipulates that environment management is an integrated effort to preserve the environmental functions encompassing organizational policies, utilization, development, maintenance, recovery, monitoring and control. This integrated effort involves land-using 
communities so that they can improve their farming within and for their own land. The communities have a strong tie with environmental conservation as a place of interaction for them and other biological and non-biological living organisms (Soerjani, 1996: 32-33 cited in Abubakar, 2011: 10).

The use of biopesticides, especially plant-based pesticides, is part of the local wisdom of the Indonesian people that has been handed down from one generation to another (Soekadar, 1998: 99). The use of plant-based pesticides has drawn a significant attention along with the emergence of the negative impacts of chemical pesticides on the human health and environment. In addition to the use of plant-based biopesticides, other alternative insect pest controls should also be developed such as the use of light traps, pheromone traps, insect sterilization techniques, as well as physical control by using colored paper.

Alternative pest control using paper is an effort to naturally attract insects to certain colors because each insect species has a capacity to adapt to different colors. This adaptation is possible due to a couple of reasons. The first reason is the navigation effect when insects are flying and the second is their capacity to adapt to their environment in order to avoid disturbances from their enemies such as predators and birds. There are several control mechanisms in agriculture such as physical control, mechanical control, eradication, and use of attractants. These types of control are acceptable because they cause no harm to the environment and health.

Biological control is one of the pest control alternatives that are considered safe to the environment and health. It has long been part of the community's local wisdom compared to the more recent control mechanisms using chemical insecticides. The latter has proven to be hugely problematic to the environment and health. Organic agriculture is the right move to foster the local wisdom of the Indonesian people.

Local wisdom is born from the awareness of human beings of their roles and functions in the environment as managers, users, and observers. The environment consists of two primary elements i.e. biological and nonbiological. Biological elements include all living bodies such as human beings, animals, plants, and microorganisms (bacteria), whereas nonbiological elements consist of air, earth, and water which complement other environmental components and form interdependence. 
The first objective of this research was to determine the community's involvement in the employment of the local wisdom of controlling insect pests in vegetable plants. The second objective was to determine the effect of using paper as a mechanical trap for the insect pests.

\section{B. Method}

This research employed a descriptive qualitative approach and experiment method by providing treatment using non-chemical pesticides. The qualitative method was used to collect the primary and secondary data through interviews and observation. Interviews with vegetable farmers were conducted to obtain the primary data, whereas observation of the farmers was conducted to obtain more accurate data. An experiment was performed by testing the use of paper of different colors as an alternative measure to control the insect pests in vegetable plants.

\section{Research Finding}

\section{Insect pest control based on local wisdom.}

Based on the result of the interviews with the vegetable farmers in Lembah Seulawah, 10 out of 30 respondents answered that they have used plant-based materials as insecticides to control insect pests in vegetable plants. The plant-based materials frequently used are garlic (Alllium sativum), castor bean seeds (Riccinus communis), aromatic plants such lemongrass and clove, as well as thorny amaranth which is a wild plant growing in berween the main crop.

Based on the local wisdom, prior to seeding and planting, it is customary for the community to examine daily weather conditions as well as the overall climate. Indonesia has two seasons; rainy and dry seasons. It is customary for people to start planting at the end of the dry season and the beginning of the rainy season between August and September The condition of the seasons will greatly affect the growth of both the plants and insect pests. In terms of insects' behavior, the reproduction of insects takes place in April, May and June. It is during the transition period from the dry to the rainy season that the population explosion of insect pests will occur. The community has been using their knowledge of the seasons as a guide to their 
agricultural activities. The above-mentioned data and facts show that the Lembah Seulawah community has been practicing appropriate timing in their vegetable cultivation with the guide of their local wisdom.

In addition to referring to the seasons, the community of Lembah Seulawah has been using plant-based materials such as leaves, fruits, stems, and roots which can potentially produce botanical insecticides. Some plants contain insecticides in their leaves such as areca palm, torch ginger, jathropa, and soursop, while others in their fruits such as areca nuts, jathropa seeds, white leadtree seeds, soursop seeds, and mahogany seeds. Other plant-based insecticides are derived from the stems such as torch ginger shoots, castor bean stalks, barks of neem plants (bak Beuem in Acehnese). Plant-based control is also part of the local wisdom in Aceh Province.

According to Entomology, mature insects are more commonly found during the dry season because the female insects do not produce many eggs during this time of the year. In the rainy season, the number of eggs produced is far greater (Borror DJ, CA Triplehorn, and NF Johnson, 1996: 106).

In relation to the above-mentioned phenomenon, the people of Lembah Seulawah have been benefitted from the period in-between the two seasons to cultivate vegetables. Their local wisdom has also allowed them to use various plants as botanical insecticides to protect their crops from insect pests.

Field observation revealed that there was quite a number of wild plants that grow among the vegetable plants such as thorny amaranth. The thorny amaranth is a very effective trap for a root nematode (Meleydigin sp). The local community has been using this plant as a biological trap in order to minimize the damage caused by the nematode to plants such as papaya and tomato. Nematodes are tiny animals in the form of microscopic worms. According to Asikin and Thamrin (2005: 336), a type of wild plants called Eleocharis dulcis is a favorite place for stem borers to lay eggs and make their nests. Thus, this plant can be appropriately used as a natural trap.

\section{Experiment of alternative control of insect pests in vegetable plants.}

The experiment in which three types of colored paper were tested indicated that on average, the largest population was found in the yellow paper (15 insects). The green paper followed with an average of 12 insects, 
whereas the red paper 11 insects. The result of the field observation conducted from March to May 2015 is presented on the following graph:

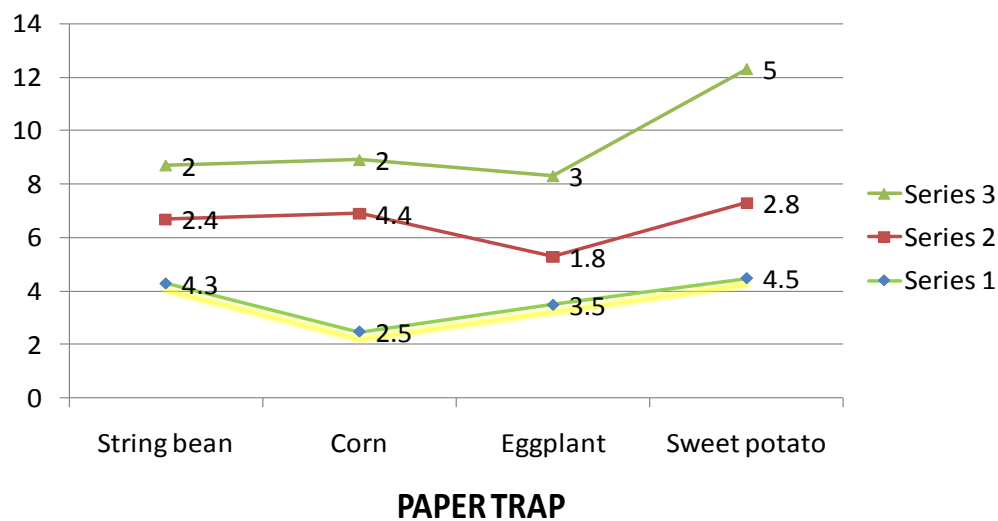

Figure 1. Average number of insects caught in paper traps

\section{Discussion}

The procedure for utilizing plant-based materials as part of the local wisdom of the Lembah Seulawah community is as follows: garlic is minced and mixed with water, then sprayed on the plants' organs. Based on the research of Asikin and Thamrin (2005: 15), 100 grams of garlic (Allium sativum L.) is mashed and mixed with 0.5 liter of water and then the mixture was put aside to form a sediment. The remaining water on the top layer was used to spray the plants. Allium satioum Linneus is a highly effective insecticide for a corn cob borer (Helicoverpa armigera). It is applied by spraying the corn cobs.

The vegetable farmers have been using the seeds of castor bean plants which have been dried and finely ground. The powder is then boiled and diluted with water before it is sprayed on the vegetable plants. Kalsum (2013:121) stated that 0.5 kilogram of castor bean seeds (Ricinus cummunis) is finely ground and boiled with 2 liters of water for 10-15 minutes. This mixture is then diluted with 4 liters of water and sprayed on the surface of the plants' leaves. $R$. communis has proven to effectively control the pest Cylas formicarius in sweet potato plants.

Besides the above-mentioned plant-based materials, lemongrass which is usually used as a natural flavor enhancer, apparently contains the chemical substance methyl eugenol $\left(\mathrm{C}_{12} \mathrm{H}_{24} \mathrm{O}_{2}\right)$ and is highly effective for 
controlling fruit flies (Bachtrocera dorsalis) in vegetable and fruit plants. Methyl eugenol is an attractant in nature, thus fruit flies will be trapped in the substance (Soekadar W., 1998: 97). The result of its application by the farmers proved the effectiveness of lemongrass in controlling the fruit flies attacking red chili and tomato plants.

Another trap plant called Eleocharis dulcis also attracts stem-boring insects to lay their eggs, thus can be used to minimize the damage to the cultivated vegetation. A study by Asikin and Thamrin (2005: 335) revealed that stem-boring insects can lay up to 6459 eggs in every hectare of the tested botanical traps. Besides the plant-based materials, mechanical traps can also be utilized by using paper of different colors such as red, yellow, and green. Adhesive material was then added on the surface.

\section{Red colored paper}

The field observation showed that the following insects were attracted to the red traps: Agromiza fasieoli (Diptera: Agromizidae), Crosidolomia binotalis (Lepidoptera), green planthopper Nepotetix apicalis (Hemiptera). The observation was performed to corn, string bean, eggplant, and sweet potato plants. The mechanical traps were only effective with mature insect pests. Some insect pests found in large number in corn plants were stem borers, cob borers, and leaf eaters. This pest is called Helocoverpa armigera from the domain of Lepidoptera. Aphids (Aphis sp.) and grasshopper Locusta sp. were also found (Kalsum, 2013: 121).

During the research, a number of predator insects which functioned as a biological control were also found in corn plants such as ladybugs (Coccinelidae), Coccopet beetles which are the natural enemy of a corn stem borer Ostrinia furnacalis. The corn plants in Lembah Seulawah were organically cultivated without any chemical pesticides. By having predators such as Coccinelidae, Cocopet, predator grasshoppers such as Mantis and Acrididae as a biological controller, the level of damage to corn stems and cobs is relatively low.

\section{Yellow colored paper}

Insects trapped in the yellow paper traps were: Spodoptera litura (Lepidoptera), crickets (Orthroptera: Acrididae), green planthoppers (Homoptera), 
Agromiza faseoli (Diptera: Agromyzidae), and predator insects (Hymenoptera). Based on the study by Amir and Untung (2013: 225), out of the three colors tested (white, blue, and yellow), the color that trapped the most insects was yellow. This is because yellow is the color of pollen on which the distant vision of insects is focused. Navigation might also affect the insects' preference of yellow paper (Nurdin, Syahril, Nusyirwan, and Yulimasni, 1999: 153)

Ari Utami, Wijaya, and Yana (2014: 253) added that out of the two colors tested namely red and white, the white colored net trapped more aphis insects. Meanwhile, the red net trapped a very small number of insects. This is closely related to the wavelength of the two colors. Red color's wavelength ranges from 625 to $40 \mu m$, which is bigger than white color whose wavelength ranges between 300-400 $\mu \mathrm{m}$. The results of this study showed that insects prefer white color to red.

\section{Green colored paper}

The insects attracted to the color green include predators (Odonata) and Collembola, green planthoppers, predators (Orthroptera), and moths. Based on the observation data, there were 12 types of insects found in the green colored paper traps. The insects' interest in green color is due to the color of plants in general as well as the need to protect themselves from their enemies. Basically, insects chose colors that resemble their own colors for protection purposes when attacked by predator enemies.

Based on the result of his research, Sunarno (2011: 131) stated that green was the color generally picked by most insects compared to transparent colors and yellow. Insects are attracted to green because it naturally resembles the color of plants' leaves and stems.

A number of research results on colors revealed that each color has its own spectrum or a distinct wavelength. Sugito, dkk. (2005: 40) added that when the wavelength of a fluorencent lamp was measured, it was discovered that the color of blue had the spectrum 4,20 $\mu \mathrm{m}$, green $4,80 \mu \mathrm{m}$, red $6,60 \mu \mathrm{m}$. Based on the wavelength measurement, it was discovered that the color of purple has a wavelength of 380-450 $\mu \mathrm{m}$, blue 450-490 $\mu \mathrm{m}$, green 490-560 $\mu \mathrm{m}$, yellow 560-590 $\mu \mathrm{m}$, orange $590-630 \mu \mathrm{m}$, and red $630-760 \mu \mathrm{m}$. 
The insects' interest in colors is caused by the intensity of light that the colors have that will have impacts on insects' behavior. The light has some attractiveness that can affect insects' behavior, hence the intensity will result in attractiveness (Alim and Harry, 2009: 23). The interest of insects in lights is an instinct that insects have in order to find shelter, eating spots, and inter-species meeting points.

Color is a process; when a light hits an object, the color will reflect the light from that object. Spectrum is part of a visible electromagnetic wave. The wavelength of the colors visible to the human eye ranges from 400 to 700 nanometers $(\mu \mathrm{m})$ and is often referred to as visible light.

The life of insects is determined by two factors: biotic and abiotic. The biotic factors consist of procreation ability, fertility, sex ratio, and survival ability. The abiotic factors are wind, air, water, and response to colors and light. Colors and light affect the behavior of insects. For example, the yellow color is associated with the color of pollen or blooming flower petals. Insects such as aphid, mites, and fruit flies are drawn to yellow color more than other insects. It has been observed that when the population of insects being trapped in a color reaches 40-60 individuals, the population of insects in that particular area is very large. When the trapped population consists of 10-30 individuals, the population is presumably smaller. When a considerable population is found in some vegetation, some controlling measures are called for. Based on the observation data, the population density in the research location is around 1215 individuals, thus no controlling actions are needed. It is believed that in this condition, the nature of the studied area is in balance. It is proven by the existence of insects' natural enemies such as predators and parasitoids.

Insects are naturally drawn to the light at all times. For example, at nighttime, when there is a large population of insects nearby some electrical lights, the insects will move towards the household lights. Take alates as an example. These are actually female termites migrating due to the mating season.

For the nocturnal type of insects such as mosquitos, moths, and blackbugs, light is an effective guide to finding the flying targets. In addition to electrical lights, the light of a full moon poses an attraction to 
the nocturnal insects during the mating period. If the mating period takes place during a full moon between $12^{\text {th }}$ and $15^{\text {th }}$ day, the increase in population is estimated to occur between $17^{\text {th }}$ and $20^{\text {th }}$ lunar day. In short, light releases mating signal to nocturnal insects.

In addition to the factor of light, the appeal of insects is also determined by the pheromone stimulus. A pheromone is a chemical stimulus produced by female insects to attract the male. Pheromones can be extracted from essentialoil-producing plants such as lemongrass, clove and patchouli. One of the pheromones that can be processed from plants is methyl eugenol, an easily vaporizable substance with captivating smell. It is an artificial pheromone that allures insects. Eugenol-producing botanical substances are called attractants because they can attract insects, thus they can also be used as an insect trap.

\section{E. Conclusion}

Based on the results of the research on the alternative control of insect pests in vegetable plants using the local wisdom approach as well as the use of paper as a mechanical trap in Lembah Seulawah Sub-district, Aceh Besar, the writer concluded the following:

1) The community of farmers in Lembah Seulawah Sub-district is still holding on to the local wisdom. The farmers are maintaining the use of plant-based pesticides to control insect pests in vegetable plants.

2) Plant-based insecticides do no leave residues harmful to the consumers' health.

3) Plant-based insecticides may be recommended as environmentally friendly insecticides to support organic farming in Indonesia.

4) Three types of paper which were experimented on i.e. red, yellow, and green were proven effective to serve as a mechanical trap for vegetable insect pests.

\section{Bibliography}

Alim, E.S., Harry, R. (2009). Piranti Perangkap Serangga Hama Dengan Intensitas Cahaya. Laporan Hasil Penelitian Tahun I Hibah Bersaing. Jakarta. UHAMKA. 
Amir, A.M., Untung S.B. (2013). Preferensi perankap warna Thrip dan Serangga lain pada tanaman Rosella (Habiscus sabdariffa Var.) Balai Penelitian Tanaman Pemanis dan Serat. Jurnal Ilmiah Green Technology. 2(3): 224-227. Malang.

Ari Utami, N.A.T., TN. Wijaya, I.D., N. Nyana. (2014). Pengaruh Penggunaan Jaring Berwarna Terhadap Kelimpahan Serangga Aphis gossypii Pada Tanaman Cabe Rawet. E-jurnal Agroteknologi Tropika. 3 (4): 251-257. Bali. Udayana.

Asikin dan Thamrin. (2005). Keanekaragaman Tumbuhan dan Serangga Dalam Mendukung Budidaya Tanaman Sayuran dan Padi di Lahan Pasang Surut. Prosiding Simposium Revitalisasi Penerapan Pengendalian Hama Terpadu Dalam Praktek Pertanian Berkelanjutan. Bogor.

Borror DJ, CA Triplehorn, NF Johnson. (1996). Pengenalan Pelajaran Serangga. Yogyakarta. Gajah Mada University Press.

Kalsum, U. (2013). Pengamatan serangan hama tanaman jagung (Zea mays L.) di Desa Banyu Urip Kecamatan Tanjung Lago Kabupaten Banyuasin. Jurnal Ilmiah Agr. IBA. 1 (2): 120-126. Palembang.

Nurdin, Syahril, Nusyirwan, dan Yulimasni. (1999). Uji Efektifitas Perangkap Kuning Untuk Mengendalikan Hama Lalat Korok Daun (Liriomiza) Pada Tanaman Kentang. Proseding Seminar Nasional. Perhimpunan Entomologi Indonesia. Bogor.

Oka, Ida Nyoman. (1993). Pertanian Berkelanjutan: Penerapan Konsep Pengendalian Hama Terpadu. Institut Pertanian Bogor.

Peraturan Menteri Pertanian Republik Indoesia Nomor: 64/Permentan/OT.140/ $5 / 2013$.

Soekadar W. (1998). Percobaan Pendahuluan Pengaruh Minyak Mimba dan Ekstrak Biji Srikaya Terhadap Mortalitas Helopestis Sp (Heteroptera: Miridae). Jurnal Perlindungan Tanaman Indonesia. 4 (2) 97-99. Jurusan Hama dan Penyakit, Yogyakarta. Universitas Gadjah Mada.

Soemarwoto, O. (2004). Ekologi Lingkungan Hidup dan Pembangunan. Jakarta. Djabatan.

Soerjani, M. (1996). Permasalahan Lingkungan Hidup dalam Tinjauan Filosofis Ekologis. dalam Abubakar, Konsep Implementasi Lembaga Adat Keujruen Blang Dengan PEMDA Dalam Meningkatkan Kesejahteraan Petani Sawah. Laporan Hasil Penelitian Hibah Fundamental. Univeristas Serambi Mekkah Banda Aceh. 
Sugito, H., Wahyu, S.B., Sofyan, F., Siti M. (2005). Pengukuran Panjang Gelombang Sumber Cahaya Berdasarkan Pola Interferensi Celah Banyak. Jurnal Berkala Fisika 8(2): 37-44. FMIPA. UNDIP.

Sunarno. (2011). Ketertarikan Serangga Hama Lalat Buah Terhadap Berbagai Papan Perangkap Warna Sebagai Salah Salah Satu Teknik Pengendalian. Jurnal Agroforestri. VI (2) 129-134. Tabelo. Halmahera.

Thamrin. Asikin. Najib. 2003. Eksplolasi Unsur Esensial Komponen Pengendalian Hama Terpadu Tanaman Lahan Rawa. Banjar Baru. Balittran.

Untung, K. (1984). Analisis Ekonomi Pengendalian Hama Terpadu. Yogyakarta. Andi Ofset.

. (1993). Pengelolaan Pengendalian Hama Terpadu. Yogyakarta. Universitas Gadjah Mada.

ZA, T. (2014). Islamic Studies dalam Pendekatan Multidisipliner (Suatu Kajian Gradual Menuju Paradigma Global). Jurnal Ilmiah Peuradeun, 2(2), 211-234. 